\title{
Geography after Babel - a view from the French province
}

\author{
M. Houssay-Holzschuch ${ }^{1, *}$ and O. Milhaud ${ }^{2, *}$ \\ ${ }^{1}$ Université Grenoble Alpes - PACTE UMR5194 (CNRS, IEPG, UJF, UPMF) - Institut Universitaire de \\ France, 14 bis avenue Marie Reynoard, 38100 Grenoble, France \\ ${ }^{2}$ Université Paris IV Sorbonne - UMR8185 ENeC, Institut de Géographie, 191 Rue Saint Jacques, \\ 75005 Paris, France \\ *These authors contributed equally to this work. \\ Correspondence to: M. Houssay-Holzschuch (myriam.houssay@normalesup.org) and \\ O. Milhaud (olivier.milhaud@paris-sorbonne.fr)
}

Received: 29 January 2013 - Revised: 7 February 2013 - Accepted: 13 February 2013 - Published: 30 May 2013

\section{Does French geography matter?}

For the past decade, an international debate has addressed the internal diversity of geography as a discipline, a diversity that is at the same time national, linguistic, and conceptual (for instance, see Gutierrez and Lopez-Nieva, 2001; Braun et al., 2003; Garcia-Ramon, 2003; Aalbers, 2004; Aalbers and Rossi, 2007; Fall and Rosière, 2008; Schuermans et al., 2010; Bajerski, 2011; Bański and Ferenc, 2013). While early on, the discussion questioned Anglo ${ }^{1}$ geography's international status, we agree with the call by Fall and Minca (2012) and others to reject simple binaries between Anglo geography and "other" geographies from the rest of the world. In keeping with this, we locate this paper's analysis within Francophone geography, not only to further highlight the diversity of "other geographies", but also to assess the geographies of power - both internal (e.g., institutional) and external (the existence of a subsystem) - to the so-called periphery (Rodriguez-Pose, 2006). In so doing, we follow Best's (2009) suggestion to use a postcolonial perspective when analyzing geographies of knowledge production.

Indeed, there are several scientific spaces, with complex hierarchies and processes of (self-) exclusion, also within the peripheries. We argue that, during the last third of the twentieth century, Francophone human geography may well have constituted a provincial subsystem, that is, a relatively closed space within the discipline. Following Wismann (2012), we also point to some of the challenges and - crucially - advan-

${ }^{1}$ Following Fall and Minca (2012:18), we choose to use this "rather informal term to mean Anglo-American, British-American or English-language geography". tages of practicing a multilingual geography and "thinking in-between languages". We will address these questions as native French speakers and mid-career tenured geographers.

\section{A view from the province}

We suggest that the notion of provincialism can usefully describe and explain French geography's position within the discipline at the end of the twentieth century. Dictionary.com ${ }^{2}$ defines provincialism as follows:

1. narrowness of mind, ignorance, or the like, considered as resulting from a lack of exposure to cultural or intellectual activity.

2. a trait, habit of thought, etc., characteristic of a provincial, a province, or the provinces.

3. a word, expression, or mode of pronunciation peculiar to a province.

4. devotion to one's own province before the nation as a whole.

These four definitions point to the subsystem's autonomy, its provincial way of functioning, its specific language, and its

\footnotetext{
${ }^{2}$ Provincialism - Dictionary.com, Collins English Dictionary - Complete $\mathcal{F}$ Unabridged 10th Edition, HarperCollins Publishers, http://dictionary.reference.com/browse/provincialism (last access: 11 November 2012). We deliberately chose an online dictionary to underline the material difficulties of access to Anglo materials from outside the Anglo sphere.
} 
hierarchical relationships to the rest of the world. We will explore them in turn to assess the hypothetical provincial quality of Francophone geography.

Before we proceed, some important caveats: first, provincialism has pejorative undertones (see definition 1), which we regret, because Francophone geography can rightfully claim many objective achievements. We certainly do not wish to imply that Francophone geographers are country bumpkins; what we mean is that their intellectual horizons and careers tend to develop within linguistic boundaries, and that these have become provincial. Second, Francophone geography has always been historically diverse, and there has always been independent, free-spirited ("franc-tireurs") geographers who have transgressed disciplinary and linguistic boundaries, delivering substantial scientific inputs in the process. We are therefore analyzing a mainstream tendency here. Thirdly, specific subfields within the discipline (e.g., physical geography, GIS, and locational analysis) have taken advantage of their more standardized publishing norms to participate in international debates held in English. Our intervention here addresses the situation in human (social, political, cultural) geography. Last, and under significant pressure (e.g., neoliberal reforms, competition for tenured jobs, and rating assessments), the French core of the Francophone subsystem is rapidly seeking to become more international, especially within younger generations; in this regard, our analysis is a diagnosis of the present situation as burdened by past inheritances.

\section{Mapping a provincial subsystem}

The Francophone province of geography can be described as a subsystem within international geography, because it has long been structured around a strong core, "peripheral" interfaces, "margins", and "dependents". The system's core has a proud national history in geography: the Vidalian school was once dominant internationally, and French was one of the main languages used at international conferences - it has - rather quaintly - remained one of the two official languages of the International Geography Union. The national disciplinary debates around concepts and geography's future has been lively and strong. This internal, deep-rooted strength might have been the main reason for both the existence and sustainability of a Francophone subsystem. It has also been sustained by steady relationships between its French core and its so-called perceived "margins," some of which are innovative and open to the world (e.g., Quebec, Francophone Switzerland, and Belgium ${ }^{3}$ ) and act as interfaces, while oth-

\footnotetext{
${ }^{3}$ Because we situate our analysis in the French core, we will not address non-French Francophone geographies here, except to insist that their position between French-speaking, English-speaking, and German-speaking geographies has given them a remarkable vitality. They have often been agents of change for French geography (Claval, 1998).
}

ers (e.g., North and West Africa) come across more as dominated peripheries, locked in a neocolonial, institutional, and financial, dependence. They have long been privileged sites for fieldwork for French geographers. Many North African and West African geographers still come to France for their $\mathrm{PhD}$, and seek to publish in French journals. Research networks and collaborations between geographers in the former colonies and geographers in France have benefited both sides, because they have offered easy international exposure and international research partners - often prerequisites to obtain funding. They also provided French geography with a welcome exposure to the other, although from a secure power position.

This subsystem could be called provincial, because it was idiosyncratic as well as relatively closed and autonomous vis-à-vis so-called international geography; as a result, it lacked exposure to international debates (definitions 1, 2, and 4). This somewhat caricaturing statement points to the fact that French authors, located in the influential core, tended to debate only geographical concepts in French and to quote mostly references in French. The following reasons help explain this situation:

1. This set of theories and references was perceived as self-sustaining. The notion of territoire/territory, for instance, as theorized by Roger Brunet (1990), Joël Bonnemaison (1981), Maryvonne Le Berre (1992), Bernard Debarbieux (1999), or Jacques Lévy (1999) is at the core of much geography work in French. It is very difficult to have an international discussion about a body of untranslated theory (Fall, 2007).

2. Outsiders' perspectives have often been considered irrelevant to local debates and have even been summarily dismissed. Ironically, this might be especially true of contributions that make use of "French theory" (Cusset, 2003; Varii Auctores, 2004), in a bizarre though ironic reversal of the disciplinary Orientalism pointed out by Fall (2012): Chivallon argues that "it is scarcely possible to speak of 'postmodern geography' in France without suspicion of scientific heresy" (2003:406).

3. The Francophone subsystem has long remained fairly sustainable, dynamic, and open to new ideas, because innovative intellectual exchanges occurred through interdisciplinary collaborations with other Francophone researchers in other social sciences (e.g., sociologists and historians) rather than through international collaborations with non-French-speaking geographers.

This subsystem was sustained by internal legitimation processes and institutional specificities (including shortcomings), achieved through local (provincial) journals, conferences, and institutions, in which a specific system of Frenchcentered norms was enforced: 
1. Peer-reviewed disciplinary journals such as L'Espace géographique (considered the flagship of French geography, founded in 1972 by Roger Brunet), the Annales de géographie (founded in 1891 by Paul Vidal de La Blache), and many other regional or thematic journals publish articles overwhelmingly written in French, written mainly by French authors. Indeed, as Bajerski (2011:308) has shown, in French journals $82 \%$ of authors and $67 \%$ of references are French. Most reviewers are also French. Conversely, gaining access to the main international journals is extremely difficult and limited: for instance, CNRS (National Center for Scientific Research), which is fairly resourceful and which funds many university research teams, does not provide access to journals such as Antipode, and only JSTOR (Journal Storage) has access to Area with a six-year delay.

2. As far as geography is concerned, institutions of learning (universities), research (CNRS), and evaluation (CNU (National Council of Universities); National Committee for Scientific Research), tended to function in French, with French norms and mostly French colleagues, with a few exceptions in the form of colleagues based in Francophone institutions, to provide an international hue.

3. Research subjects - for instance, PhD subjects - deal mostly with the French-speaking universe: $32 \%$ of all the PhDs submitted in France between 1990 and 1994 dealt with France and $44 \%$ with former French colonies (Knafou, 1997).

4. There was a general lack of international mobility, due to financial constraints and the lack of supporting structures. For instance, sabbaticals are very few -15 to 20 per year only offered by the main source, the CNRS between 2000 and 2008 for 1100 to 1300 possible candidates - and difficult to obtain - having had a sabbatical in the previous $10 \mathrm{yr}$ acts as a disqualifier for a sabbatical from the CNU, the second main provider nationally ${ }^{4}$. Also, all university lecturers must teach $192 \mathrm{~h}$ per year (that is, $8-10$ courses); this comparatively heavy teaching load is made heavier by the lack of teaching assistants to help mark exams, together with a shortage of support staff, which leaves many routine administrative tasks to faculty.

4 Source: Bilan de la mandature 2000-2004 de la section 39 (http://slr39.free.fr/article.php3?id_article=35, last access: 6 February 2013); Rapports de conjuncture de la section 39 (2003: http://slr39.free.fr/article.php3?id_article=21; 2010: http://www.cnrs.fr/comitenational/doc/rapport/2010); participant observation of one of the authors for the 39th section of the Comité national 2004-2008 and the CNU since 2012.
5. Building a successful academic career in France requires a French-centered publishing and networking strategy.

Mastering this French-centered, provincial subsystem was a prerequisite to become an academic geographer in France. On top of all this, knowing, using, and publishing within the Anglo theoretical framework - a huge investment in own money and time - has long been perceived as very tough and probably not worth the effort.

\section{The issue of language: mourning translation, and beyond}

Last, the Francophone subsystem is also structured by language, and by a single but international language at that ${ }^{5}$, which corresponds to definition 3 of provincial. The question of language in geography is a fascinating and expanding research field. Certainly, being able to write in English - and to pay for editing/proofreading - is the first obstacle to overcome when one wants to enter international debates and has little to do with scientific relevance (Garcia-Ramon, 2003; Aalbers, 2004). The main journals' persisting Anglo bias has been well documented (see Gutierrez and LopezNieva, 2001; Vaiou, 2003; Bański and Ferenc, 2013). However, in our view, this is just one part of the problem. Crucial disciplinary keywords can have very different meanings in various languages, which leads to very different ways of thinking. To name just one example, Anglo geographical debates often rely on the dialectic between space and place. Because of different conceptualizations of place (lieu) and space (espace), this dialectic is meaningless in French. Lieu is not a "humanized space" nor a "[setting] in which social relations and identity are constituted" (Johnston, 2000:582sq). In Francophone geography and particularly in the widely used Dictionnaire de la géographie et de l'espace des sociétés, lieu is mainly a kind of space within which distance is considered irrelevant. Unlike with Anglo conceptualizations, the question of a sense of place, or the opposition between place and space to analyze the relationships between local specificities and general processes, are not central to the debate. By contrast, the Dictionnaire does not oppose lieu to space but to aire (area), a kind of space in which distance is considered relevant (Lévy and Lussault, 2003). Territoires are understood as an example of an areal space with topographical metrics, as opposed to réseaux (networks), which have topological metrics; metrics being a way of measuring distance within a space. Hence, Francophone geographical thought is not structured by the place/space dialectic, but by a trialectical relationship between lieu, réseau, and territoire. As a result, translating geographical texts is anything but straightforward. Translating a concept can lead to the loss of some

\footnotetext{
${ }^{5}$ It would be interesting here to draw a comparison with Russian or Arab geographies, which are also elaborated in an international language.
} 
of the original connotations and relational meanings (Olwig, 2002). A fundamental keyword such as space or place is necessarily a node of intertextuality: it refers to other texts, other images, and other meanings that cannot circulate simultaneously through translation. As a result, we must mourn for the loss of translation as equivalence (Ricoeur, 2004).

Furthermore, is it at all useful - as opposed to ethically justified and desirable - to seek to overcome these linguistic and national boundaries within geography? Surely, social scientists - and especially geographers - cannot be bound to a single way of seeing the world: remaining provincial, limited in outlook, and unsophisticated is a failure in the ethics of science. But are these (perhaps too) foreign ideas useful to understanding one's research object? Also, to what extent is it a scientific problem to have never read any geography literature in Arabic, Russian, Brazilian, or Chinese? Beyond Anglo geography's hegemony and the theoretical gatekeeping in Anglo journals, as well as the strategies people might implement to circumvent them, why should anyone be compelled to use foreign ideas to make their point? Imported theories do not inherently deserve more respect than locally rooted ones. As geographers, we know that scale matters. Applying this idea to the geography of knowledge production would mean that what is scientifically relevant at a global or international level might not be relevant at a local level, and vice versa. While such a distinction deserves careful consideration, it also holds risks: first, we risk legitimating the exclusion of subaltern discourses; second, we may overlook the ethical, scientific, and political question of who decides what is relevant, useful, and operable and what is not. This debate comes up against the distinction between the ethics of accessibility and the pragmatics of science. We care, but does it matter?

We believe it does, if we consider translation an opportunity for increased reflexivity (Bruns and Zichner, 2009; Crane et al., 2009). Certainly, moving and thinking between languages, probing their points of friction as well as "les champs de force que les langues créent entre elles, avec des problèmes qui naissent de leurs différences et parfois de leurs convergences - apparentes ou réelles, et c'est tout le problème" (Wismann, 2012:13) might lead to new ways of conceptualizing and articulating concepts. Even better if this happens between more than two languages, in order to go beyond the English/non-English binary, also linguistically. As Wismann (2012:102) notes, the "Babel effect" might have been the most productive moment in human history. New ways of thinking can indeed be found in translation, as long as translation is understood and practiced as a process that is never-ending, dialogical, and fraught with heuristic tensions.

Acknowledgements. We are grateful to Kye Askins and Jo Norcup for convening the initial RGS/IBG session in which we presented some of these ideas, as well as to Olivier Graefe and Elisabeth Peyroux for bringing the Wismann reference to our attention and to the many persons with whom we discussed this topic over the years. Thanks also to Johan Emerson Grobler for proofreading.
Edited by: F. Klauser

Reviewed by: one anonymous referee

\section{References}

In line with our own hypothesis, we propose an experimental bibliography, centered around the main references in French, and including contributions by "other" geographers (i.e. based in non-Anglo institutions), Anglo references being - for once peripheral.

Aalbers, M. B.: Creative destruction through the Anglo-American hegemony: a non-Anglo-American view on publications, referees and language, Area, 36, 319-322, 2004.

Aalbers, M. B. and Rossi, U.: A coming community: young geographers coping with multi-tier spaces of academic publishing across Europe, Soc. Cult. Geogr., 8, 283-302, 2007.

Bajerski, A.: The role of French, German and Spanish journals in scientific communication in international geography, Area, 43, 305-313, 2011.

Bański, J. and Ferenc, M.: forthcoming, preprint, "International” or "Anglo-American" journals of geography? Geoforum, 45, 285295, doi:10.1016/j.geoforum.2012.11.016, 2013.

Best, U.: The invented periphery: constructing Europe in debates about "Anglo hegemony" in geography, Soc. Geogr., 4, 83-91, doi:10.5194/sg-4-83-2009, 2009.

Bonnemaison, J.: Voyage autour du territoire, L'Espace géographique, 10, 249-262, 1981.

Braun, B., Vaiou, D., Yiftachel, O., Sakho, H., Chaturvedi, S., Timár, J., and Minca, C.: Guest editorials, Environ. Plann. D., 21, 131-168, 2003.

Brunet, R: Le Territoire dans les turbulences, GIP Reclus, Montpellier, France, 1990.

Bruns, B. and Zichner, H.: Übertragen - Übersetzen - Aushandeln? Wer oder was geht durch Übersetzung verloren, oder kann etwas gewonnen werden?, Soc. Geogr., 4, 25-37, doi:10.5194/sg-4-252009, 2009.

Chivallon, C.: Country reports: a vision of social and cultural geography in France, Soc. Cult. Geogr., 43, 401-408, 2003.

Claval, P.: Histoire de la géographie française de 1870 à nos jours, Nathan, Paris, France, 1998.

Crane, L. G., Lombard, M. B., and Tenz, E. M.: More than just translation: challenges and opportunities in translingual research, Soc. Geogr., 4, 39-46, doi:10.5194/sg-4-39-2009, 2009.

Cusset, F.: French theory: Foucault, Derrida, Deleuze \& Cie et les mutations de la vie intellectuelle aux Etats-Unis, La Découverte, Paris, France, 2003.

Debarbieux, B.: Le territoire: histoires en deux langues, a bilingual (his-)tory of territory, in: Discours scientifiques et contextes culturels. Géographies françaises et britanniques à l'épreuve postmoderne, edited by: Chivallon, C., Ragouet, P., and Samers, M., Maison des sciences de l'homme d'Aquitaine, Bordeaux, France, 33-46, 1999.

Fall, J. J.: Lost geographers: power games and the circulation of ideas within Francophone political geographies, Prog. Hum. Geog., 31, 195-216, 2007.

Fall, J. J.: Reading Claude Raffestin: pathways for a critical biography, Environ. Plann. D, 30, 173-189, 2012. 
Fall, J. J. and Minca, C.: Not a geography of what doesn't exist, but a counter-geography of what does: Rereading Giuseppe Dematteis' Le Metafore della Terra, Prog. Hum. Geog., doi:10.1177/0309132512463622, in press, 2012.

Fall, J. J. and Rosière, S.: Guest Editorial: On the limits of dialogue between Francophone and Anglophone political geography, Polit. Geogr., 27, 713-716, 2008.

Garcia-Ramon, M. D.: Globalization and international geography: the questions of languages and scholarly traditions, Prog. Hum. Geog., 27, 1-5, 2003.

Gutierrez, J. and Lopez-Nieva, P.: Are international journals of human geography really international?, Prog. Hum. Geog., 25, 5369, 2001.

Johnston, R. J., Gregory, D., Pratt, G., and Watts, M.: The dictionary of human geography, Blackwell, Oxford, United Kingdom, Malden, Mass., United States of America, 2000.

Knafou, R.: L'état de la géographie: autoscopie d'une science, Belin, Paris, France, 1997.

Le Berre, M.: Territoires, in: Encyclopédie de la géographie, edited by: Bailly, A., Ferras, R., and Pumain, D., Economica, Paris, France, 601-622, 1992.
Lévy, J.: Le Tournant géographique: penser l'espace pour lire le monde, Belin, Paris, France, 2000.

Lévy, J. and Lussault, M.: Dictionnaire de la géographie et de l'espace des sociétés, Belin, Paris, France, 2003.

Olwig, K. R.: The Duplicity of Space: Germanic "Raum" and Swedish "Rum" in English Language Geographical Discourse, Geogr. Ann. B, 84, 1-17, 2002.

Ricoeur, P: Sur la traduction, Bayard, Paris, France, 2004.

Rodriguez-Pose, A: Is there an "Anglo-American" domination in human geography? And, is it bad?, Environ. Plann. A, 38, 603610, 2006.

Schuermans, N., Meeus, B., and De Maesschalck, F.: Is there a world beyond the Web of Science ? Publication practices outside the heartland of academic geography, Area, 42, 417-424, 2010.

Vaiou, D.: Radical debate between "local" and "international": a view from the periphery, Environ. Plann. D., 21, 133-137, 2003.

Varii Auctores, Débat: Le postmodernisme en géographie, L'Espace géographique, 33, 6-37, 2004.

Wismann, H.: Penser entre les langues, Albin Michel, Paris, France, 2012. 